\title{
Taksonomia afazji - kryteria klasyfikacji oraz rodzaje zespołów zaburzeń
}

\section{Aphasia Taxonomy - the Classification Criteria and the Types of Disorders}

\author{
Słowa kluczowe: afazja, podział afazji, diagnoza i terapia afazji \\ Keywords: aphasia, taxonomy of aphasia, aphasia diagnosis and therapy
}

\section{Streszczenie}

W artykule zestawiono istotne kryteria podziałów afazji, które prezentują różne metody podejścia do schorzenia. Omówiono klasyczne postacie afazji, nieklasyczne postacie afazji oraz podział afazji ze względu na stanowiska wybranych autorów. Każde przyjęte kryterium zostało wzbogacone o opisy najważniejszych właściwości danego typu afazji, spotykanych w praktyce logopedycznej. Przedstawiono także współczesne podejście do diagnozy i terapii tego zaburzenia.

* Klinika Rehabilitacji Dziecięcej z Ośrodkiem Wczesnej Pomocy Dzieciom Upośledzonym „Dać Szansę", Uniwersytecki Dziecięcy Szpital Kliniczny, ul. Waszyngtona 17, 15-274 Białystok; Uniwersytet Medyczny w Białymstoku, Wydział Nauk o Zdrowiu, ul. Jana Kilińskiego 1, 15-089 Białystok, e-mail: karolina007@poczta.onet.pl, ORCID: https://orcid.org/0000-0003-2886-7602.

** Klinika Rehabilitacji Dziecięcej z Ośrodkiem Wczesnej Pomocy Dzieciom Upośledzonym „Dać Szansę”, Uniwersytecki Dziecięcy Szpital Kliniczny, ul. Waszyngtona 17, 15-274 Białystok; Uniwersytet Medyczny w Białymstoku, Wydział Nauk o Zdrowiu, ul. Jana Kilińskiego 1, 15-089 Białystok, e-mail: zawada.bozena@wp.pl., ORCID: https://orcid.org/0000-0002-1915-4320.

*** Klinika Neurologii i Rehabilitacji Dziecięcej, Uniwersytecki Dziecięcy Szpital Kliniczny, ul. Waszyngtona 17, 15-274 Białystok; Uniwersytet Medyczny w Białymstoku, Wydział Nauk o Zdrowiu, ul. Jana Kilińskiego 1, 15-089 Białystok, e-mail: justynakackielo@gmail.com, ORCID: https://orcid.org /0000-0003-2006-8670.

**** Klinika Rehabilitacji Dziecięcej z Ośrodkiem Wczesnej Pomocy Dzieciom Upośledzonym „Dać Szansę”, Uniwersytecki Dziecięcy Szpital Kliniczny, ul. Waszyngtona 17, 15-274 Białystok; Uniwersytet Medyczny w Białymstoku, Wydział Nauk o Zdrowiu, ul. Jana Kilińskiego 1, 15-089 Białystok, e-mail: maciej.samusik@gmail.com, ORCID: https://orcid.org/0000-0002-2758-0098. 


\section{Abstract}

The article summarizes the important criteria for aphasia divisions, which present different methods of approaching the disease. Discussed: classical forms of aphasia, non-classical forms of aphasia, aphasia division by the positions of selected authors. Each adopted criterion has been enriched with descriptions of the most important properties of a given type of aphasia, encountered in speech therapy. A contemporary approach to the diagnosis and therapy of the above disorder is also presented.

\section{Wprowadzenie}

Afazja to zaburzenie, utrata oraz brak rozumienia mowy, spowodowane nieprawidłowościami w obrębie kory mózgowej. Istnieje wiele definicji afazji, jednak każda $\mathrm{z}$ nich interpretuje ją w podobny sposób. Badania nad afazją jako dziedziną interdyscyplinarną przedstawiają różne stanowiska, co owocuje wielorakimi kryteriami podziału. W literaturze wyróżnia się ponad dwieście różnych klasyfikacji. Większość autorów jest jednak zgodna co do tego, że afazja to zaburzenie tworzenia, rozumienia i odtwarzania mowy na skutek korowych bądź podkorowych uszkodzeń ośrodków mowy. Procesy biorące udział w powstawaniu mowy były pierwszymi, w przypadku których opisano charakterystyczne rejony funkcjonalno-anatomiczne mózgowia. Należy również nadmienić, że w badaniach nad językowymi zdolnościami człowieka zazwyczaj koncentrowano się na lewej półkuli mózgu [Krajna, 2005; Webb, Adler, 2017, s. 25-26; Papathanasiou, Coppens, 2018, s. 3-5].

Głównym celem artykułu jest przedstawienie oraz uporządkowanie zróżnicowanych opisów typów afazji na podstawie dostępnej literatury. Natomiast celem szczegółowym jest przybliżenie istoty i przebiegu zaburzenia.

\section{Klasyczne (korowe) postacie afazji}

Klasyczne ujęcie afazji wiąże się najczęściej z uszkodzeniem tzw. obszaru mowy, znajdującego się w korze mózgowej, mającej strategiczne znaczenie dla komunikacji. Tworzą go miejsca położone w okolicy bruzdy bocznej, czyli okolica Broki zlokalizowana w płacie czołowym oraz okolica Wernickego w płacie skroniowym, a także ich połączenie. Istnieją różne kategorie diagnostyczne przedstawiające afazję, jednak rodzaje wyodrębnione przez Wernickego i Brokę są jednymi z najważniejszych. Podstawą do rozpoznania rodzaju zaburzeń jest ocena następujących czynności mowy: rozumienia słuchowego, nazywania (na podstawie desygnatu), powtarzania oraz mowy spontanicznej [Bitniok, 2007; Jodzio, Nyka, 2008]. 


\section{Afazja ruchowa}

Afazja ruchowa nazywana jest również afazją Broki, motoryczną lub ekspresyjną. Występują w niej zaburzenia nazywania na głos, spontanicznego wypowiadania się i powtarzania. Pacjent dość dobrze rozumie mowę, ale nie potrafi płynnie artykułować. Wymowa pozbawiona jest prawidłowej linii melodycznej. Przyczyną tych trudności jest defekt $w$ funkcjonowaniu mięśni narządów artykulacyjnych, a nie ich porażenie. Chory z afazją ruchową powtarza wcześniejsze słowo bądź głoskę, nie potrafi stworzyć poprawnego zdania pod względem składniowym i gramatycznym. Często pomija czasowniki, przyimki i spójniki. Wypowiadane przez pacjenta $\mathrm{z}$ afazją ruchową zdania są bardzo uproszczone, myli on przypadki, czasy i tryby. Nie sprawia mu jednak wielkiej trudności wypowiadanie pojedynczych głosek bądź często używanych, prostych słów. Trudności pojawiają się jednak w czytaniu, zwłaszcza na głos (aleksja) i pisaniu (agrafia). Wyniki badań neuroobrazowych u chorych $\mathrm{z}$ afazją ruchową wykazują uszkodzenie okolicy Broki, natomiast zaawansowany zespół objawów można stwierdzić przy uszkodzeniu bardziej rozległym, obejmującym także struktury podkorowe [Pąchalska, 2012; Wnukowska, 2013].

\section{Afazja czuciowa}

Afazja czuciowa nazywana jest również afazją Wernickego, receptywną, sensoryczną lub percepcyjną. Jej cechą charakterystyczną jest upośledzenie rozumienia mowy - pacjent nie potrafi różnicować jej dźwięków. W lżejszych przypadkach zaburzenia ograniczają się tylko do dłuższych zdań, natomiast w cięższych obejmują także proste polecenia czy słowa. Chory podczas mówienia zamienia głoski i słowa podobne brzmieniowo, dodaje na końcach wyrazów dodatkowe sylaby, ma przyspieszone tempo mowy. Deficyt kontroli słuchowej oraz wymienione wyżej błędy popełniane przez chorego powodują, że wypowiedzi są niezrozumiałe. Mimo że zdania wypowiadane przez chorego nie tworzą logicznej całości, są wypowiadane bardzo płynnie, z prawidłowo zachowaną linią melodyczno-intonacyjną. Objawami towarzyszącymi afazji czuciowej są agrafia i aleksja. Zazwyczaj za przyczynę afazji czuciowej uznaje się uszkodzenie okolicy Wernickego, ale wiadomo, że jej lokalizacja jest mało wyraźna, a co najważniejsze - osobniczo zróżnicowana. W związku z powyższym obecnie za przyczynę uznaje się uszkodzenie większego obszaru mózgu, w tym miejsc połączeń płatów: potylicznego, ciemieniowego i skroniowego.

\section{Afazja kondukcyjna}

Afazja kondukcyjna zwana jest również afazją przewodzenia, aferentną, ruchową lub centralną. Jej cechą charakterystyczną jest zaburzone powtarzanie tekstu przy względnie prawidłowym rozumieniu mowy i płynnej wymowie, zniekształconej jedynie parafazjami głoskowymi. Pacjent proszony o powtórzenie danej frazy zniekształca ją, zwłaszcza jeżeli chodzi o słowa wielosylabowe oraz dłuższe zdania. Ma świadomość swoich błędów i zazwyczaj próbuje nieudolnie je korygować. Chory 
$\mathrm{z}$ afazją kondukcyjną często nie potrafi nazywać desygnatów, pojawiają się u niego problemy w głośnym czytaniu i zapisywaniu ze słuchu. W bardzo ciężkich przypadkach pojawiają się także łagodne zaburzenia w rozumieniu mowy, szczególnie skomplikowanej gramatycznie i logicznie. Lokalizacja miejsca w mózgu, którego uszkodzenie mogłoby powodować afazję kondukcyjną, nie jest do końca poznane, jednak przyjmuje się, że jest to uszkodzenie powiązań łączących okolice Broki i Wernickego [Pąchalska, 2012; Wnukowska, 2013].

\section{Afazja transkorowa}

Afazja transkorowa jest odwrotnością afazji kondukcyjnej pod względem objawów. Chory potrafi powtarzać słyszane frazy, ale występują zaburzenia rozumienia: mowy - postać czuciowa (sensoryczna), mowy spontanicznej - postać ruchowa (motoryczna) lub obu wyżej wymienionych czynności jednocześnie - postać mieszana. Za przyczynę czuciowej afazji transkorowej uznaje się uszkodzenie korowo-podkorowe (za okolicą Wernickego). Warto wspomnieć, że w literaturze transkorowa afazja czuciowa zestawiana jest $\mathrm{z}$ afazją Wernickego. Natomiast transkorowa afazja ruchowa (motoryczna) porównywana jest do afazji Broki. W związku z tym za przyczynę występowania drugiego typu afazji transkorowej uważa się uszkodzenie części przedczołowej mózgu (w tym włókien biegnących do okolicy Broki) [Ambrosius, Mejnartowicz, Kozubski, 2003; Wójcik, 2011].

\section{Afazja nominacyjna}

Afazja nominacyjna dawniej zwana była afazją amnestyczną, a obecnie anomią. Zazwyczaj większość pacjentów chorych na afazję ma problemy z nazywaniem przedmiotów - w afazji nominacyjnej jest to szczególnie widoczne. Występują również zaburzenia innych czynności, jednak są one dużo łagodniejsze. Zaburzenie nominacyjnej funkcji mowy można uznać za pierwotne, gdyż nie jest powodowane przez inne objawy charakterystyczne dla afazji, na przykład problemy artykulacyjne. Chory, będąc w określonej sytuacji komunikacyjnej, nie potrafi przypomnieć sobie potrzebnego słowa, mówi „okrężnie”, próbując opisać cechy lub funkcje przedmiotu. Charakterystyczne jest również podawanie nazwy zbliżonej znaczeniowo (np. samolot - helikopter). Pacjent nie ma natomiast problemów ze wskazywaniem. Anomia niekiedy ma wybiórczą naturę, pacjent nie potrafi przypomnieć sobie słów tylko z pewnej kategorii. Anomia bywa traktowana jako dobra prognoza dla afatyka, gdyż jest objawem „zejściowym” dla afazji bądź sugeruje ustąpienie objawów. Anomia jest powszechnym objawem afazji, dlatego trudno ściśle określić jej neuroanatomiczne korelacje. Przyjmuje się jednak, że afazja nominacyjna pojawia się częściej przy uszkodzeniu tylnej części półkuli dominującej dla mowy [Nocoń i wsp., 2008]. 
Tabela 1. Charakterystyka czynności mowy w poszczególnych zespołach afazji

\begin{tabular}{|c|c|c|c|c|}
\hline \multirow{2}{*}{ Rodzaj afazji } & \multicolumn{4}{|c|}{ Czynność mowy } \\
\hline & Rozumienie & Nazywanie & Powtarzanie & Mowa spontaniczna \\
\hline Ruchowa & $\begin{array}{l}\text { Zbliżone } \\
\text { do normy }\end{array}$ & $\begin{array}{l}\text { Często } \\
\text { zaburzone }\end{array}$ & Zawsze zaburzone & $\begin{array}{l}\text { Niepłynna, zawsze } \\
\text { zaburzona, z objawami } \\
\text { perseweracji i agramatyzmu }\end{array}$ \\
\hline Czuciowa & $\begin{array}{l}\text { Zawsze } \\
\text { zaburzone }\end{array}$ & $\begin{array}{l}\text { Często } \\
\text { zaburzone }\end{array}$ & $\begin{array}{l}\text { Płynne, lecz } \\
\text { zawsze zaburzone, } \\
\text { z przewagą parafrazji, } \\
\text { kontaminacji i/lub } \\
\text { neologizmów }\end{array}$ & $\begin{array}{l}\text { Płynna, lecz językowo } \\
\text { zniekształcona, z objawami } \\
\text { parafrazji, kontaminacji i/lub } \\
\text { neologizmami }\end{array}$ \\
\hline Kondukcyjna & $\begin{array}{l}\text { W normie } \\
\text { lub zbliżone } \\
\text { do normy }\end{array}$ & $\begin{array}{l}\text { Często } \\
\text { zaburzone }\end{array}$ & Zawsze zaburzone & $\begin{array}{l}\text { Płynna, lecz językowo } \\
\text { zniekształcona, z objawami } \\
\text { parafrazji głoskowych }\end{array}$ \\
\hline $\begin{array}{l}\text { Transkorowa } \\
\text { ruchowa }\end{array}$ & W normie & Zróżnicowane & W normie & $\begin{array}{l}\text { Niepłynna, zubożona, } \\
\text { z przewagą perseweracji } \\
\text { i stereotypów } \\
\text { konwersacyjnych }\end{array}$ \\
\hline $\begin{array}{l}\text { Transkorowa } \\
\text { czuciowa }\end{array}$ & $\begin{array}{l}\text { Zawsze } \\
\text { zaburzone }\end{array}$ & $\begin{array}{l}\text { Często } \\
\text { zaburzone }\end{array}$ & $\begin{array}{l}\text { W normie lub } \\
\text { zbliżone do normy }\end{array}$ & $\begin{array}{l}\text { Płynna, lecz językowo } \\
\text { zniekształcona, z objawami } \\
\text { anomii, perserwacji, } \\
\text { parafrazji i echolalii }\end{array}$ \\
\hline Nominacyjna & $\begin{array}{l}\text { Zbliżone } \\
\text { do normy }\end{array}$ & $\begin{array}{l}\text { Zawsze } \\
\text { zaburzone }\end{array}$ & W normie & $\begin{array}{l}\text { Płynna, w normie lub } \\
\text { zbliżona do normy, } \\
\text { z objawami anomii }\end{array}$ \\
\hline
\end{tabular}

Źródło: Pąchalska, 2012.

\section{Nieklasyczne postacie afazji}

Obecne badania nad afazją wykraczają poza klasyczne opisy tego schorzenia, które zazwyczaj ograniczane były do ustabilizowanego i ogniskowego uszkodzenia lewej półkuli mózgu. Klasyczne opisy afazji zostały uzupełnione o bardziej szczegółowe przyczyny, uwzględniające również plastyczność mózgu. Należą do nich: wybiórcze uszkodzenia podkorowych jąder mózgu, uszkodzenia prawej półkuli mózgu oraz postępujące choroby otępienne mózgu.

\section{Afazja po uszkodzeniu jąder podkorowych}

Wyróżnia się dwa typy afazji po uszkodzeniu jąder podkorowych: afazję wzgórzową oraz afazję prążkowo-torebkową. Najczęstszymi zaburzeniami językowymi w afazji wzgórzowej są: zaburzenia nazywania i rozumienia, problemy ze spontaniczną wypowiedzią (czasem mutyzm lub afonia). Obserwuje się tendencję do zmian całych słów - parafrazji werbalnej, a także głoskowej i perseweracji. Zmiany we wzgórzu powodują też zaburzenia pamięci, uwagi oraz wzroku. W celu podkreślenia 
odmienności tego schorzenia oraz jego podobieństwa do afazji transkorowej niekiedy stosuje się określenie afazja subtranskorowa. Natomiast afazja prążkowo-torebkowa jest konsekwencją uszkodzenia jądra ogoniastego oraz skorupy i istoty białej, która je rozdziela. W afazji prążkowo-torebkowej oprócz ogólnych problemów językowych, przejawiających się w postaci zaburzenia rozumienia skomplikowanych składniowo wypowiedzi, występują też niemające charakteru afatycznego podstawowe trudności artykulacyjne. Dobrym przykładem dla wyjaśnienia istoty tego typu afazji jest choroba Parkinsona, w której uszkodzone prążkowie powoduje obniżoną wysokość oraz natężenie głosu, spowolnione tempo mowy, monotonną intonację, mamrotanie, mimowolne powtarzanie i mikrografię [Jodzio, Nyka, 2008].

\section{Zaburzenia językowe po uszkodzeniu prawej półkuli}

Uszkodzenie prawej półkuli mózgu powikłane zaburzeniami podobnymi do objawów uszkodzenia lewej półkuli jest przykładem afazji skrzyżowanej, którą diagnozuje się u pacjenta praworęcznego ze zmianą w prawej półkuli. Jest to jednak bardzo rzadka odmiana afazji o mieszanym i trudnym do scharakteryzowania obrazie klinicznym. Najbardziej typowe skutki uszkodzeń prawej półkuli mają zazwyczaj nieafatyczny charakter. Wielu pacjentów na ogół dobrze radzi sobie z rozwiązywaniem testów badających afazję, jednak słabo wypada w szczegółowych badaniach systemu fonologicznego. Chorzy z prawostronną lokalizacją ogniska mają tendencję do pomyłek podczas szybkiego pisania, dochodzi do reduplikacji i omijania liter, czasem słów. Problemami semantycznymi są zaś nieprawidłowe przeciwieństwa podawane przez chorego oraz redukcja wypowiadanych przymiotników. Specyfikę zaburzeń w komunikowaniu się osób z uszkodzeniem prawej półkuli najlepiej widać, rozpatrując język ze strony jego funkcji komunikacyjnej. Charakterystycznymi elementami w mowie chorego są: przesadne uszczególawianie, nieadekwatne komentarze, redukowanie informacji istotnych na rzecz nowych wątków, kłopoty z wyczuciem kontekstu rozmowy, brak zrozumiałości przenośni, problemy z interpretacją stanu emocjonalnego rozmówcy [Lundgren, Brownell, 2016].

\section{Afazja w zespołach otępiennych}

Najczęściej występującą postacią zespołu otępiennego jest choroba Alzheimera. $\mathrm{W}$ przebiegu tego schorzenia dochodzi do stopniowego zaniku płatów skroniowych, co powoduje problemy z pamięcią, a także odbiera pacjentowi możliwość komunikowania się. W początkowych stadiach obserwuje się zaburzenia fluencji, a następnie rozumienie mowy się pogarsza, co mocno kontrastuje z poprawnym powtarzaniem. W końcu zaburzenia te diagnozuje się jako transkorową afazję czuciową. Osobom dotkniętym tą chorobą towarzyszą zaburzenia dyskursu, przez co ich wypowiedzi są chaotyczne i nie mają charakteru informacyjnego. Trudności językowe przyjmują postać zaburzeń sprawności leksykalno-semantycznych, które w literaturze opisywane są jako mowa z ograniczoną liczbą pojęć i niskim zasobem słownictwa (tzw. 
pusta mowa). Dodatkowo obserwuje się obniżony poziom gotowości słownej. Największe problemy występują z tworzeniem własnych wypowiedzi i ich inicjacją, pacjenci często używają zwrotów znanych, stereotypowych, dodatkowo stosując echolalię [Obler, Albert, Helm-Esabrooks, 1985; Kindell, Griffiths, 2006, s. 201-237].

\section{Podział afazji według wybranych autorów}

\section{Model afazji według Romana Jacobsona}

W modelu Jacobsona system językowy jest ograniczany przez dwie osie: oś syntagmatyczną, odpowiadającą za budowanie kontekstu i łączenie wyrażeń w ciągi syntaktyczne i oś paradygmatyczną, która jest odpowiedzialna za powiązanie danego słowa z pewnego rodzaju „rodziną” słów poprzez kod językowy. Zgodnie z organizacją afazji w sposób dwuosiowy w każdym odrębnym znaku językowym istnieją dwa układy. Pierwszy nazywany jest układem kombinacji. Każdy znak zbudowany jest bowiem ze znaków składowych bądź występuje wyłącznie w kombinacji z innymi znakami, więc każda mniejsza jednostka jest wykorzystywana jako kontekst większej lub/i bardziej złożonej jednostki językowej. W kolejnym układzie (selekcji) istnieje wiele możliwości, które implikują zastąpienie jednej drugą, gdyż pod pewnym względem są lub mogą być równoważne, a pod innym różne. W związku z tym afazję można podzielić na podstawie zaburzenia jednego z układów na [Jakobson, 1964]:

- afazję kombinacji (przyległości, styczności) - jest ona zakłóceniem polegającym na budowaniu nieprawidłowych kontekstów oraz sądów; potwierdza pogląd, iż schorzenie to nie musi objawiać się tylko brakiem słów; w tym typie afazji nie brakuje wyrazów, natomiast zakłócona zostaje możliwość tworzenia kontekstu - nawet na poziomie zdania; skutkuje to licznymi agramatyzmami i stylem telegraficznym;

- afazję selekcji (substytucji, podobieństwa) - jest to brak zdolności wybierania wyrażeń z rodzin wyrazów; charakterystycznym jej przejawem jest to, iż pacjent nie potrafi spontanicznie rozpocząć wypowiedzi, natomiast kontynuowanie rozmowy nie sprawia mu problemu; afazja selekcji jest swoistym zaprzeczeniem afazji kombinacji, pacjent tym lepiej używa języka, im bardziej w danym momencie zależy on od kontekstu.

\section{Klasyfikacja według Bożydara Kaczmarka}

Bożydar Kaczmarek przyjmuje dwojaki charakter językowych zaburzeń w afazji, który został wcześniej zaproponowany przez Jacobsona. Modyfikuje on jednak kategorie zaburzeń, czyli selekcji i łączenia symboli językowych. Klasyfikuje przejawy owych zaburzeń w różnych podsystemach języka. Zgodnie z propozycją Kaczmarka zakłócenie selekcji i łączenia symboli językowych realizowane jest $\mathrm{w}$ różnych 
podsystemach. W związku z powyższym w afazji syntagmatycznej wyróżnia się cztery rodzaje objawów:

- afazję fototaktyczną - pacjent wypowiada tylko pojedyncze głoski, gdyż nie potrafi łączyć fonemów w sylaby;

- afazję morfologiczną - brak umiejętności łączenia sylab w wyrazy, przy czym zdolność tworzenia sylab jest zachowana;

- afazję syntaktyczną - zdania tworzone przez pacjenta są agramatyczne;

- afazję tekstową - zachowana jest umiejętność tworzenia zdań, jednak pacjent nie potrafi tworzyć długich tekstów [Sawa, 1990; Kaczmarek, 1995].

Przy afazji paradygmatycznej wyróżnione zostały trzy postaci [Kaczmarek, 1995]:

- afazja fonologiczna - utracone zostały zdolności dopasowania i wyboru fonemów do struktur językowych; występuje w dwóch formach:

- afazja akustyczna - polega na zatarciu się w umyśle chorego słuchowego modelu głoski; pacjenci mają zaburzoną kontrolę słuchową;

- afazja kinemiczna - występuje w postaci trudności typowo artykulacyjnych; pacjenci zamieniają głoski podobne pod względem miejsca artykulacji, na przykład pies - piec;

- afazja leksykalna - jest to zakłócenie selekcji leksemów, co skutkuje trudnościami w odnalezieniu prawidłowych określeń; zamiany wyrazów mogą występować na podstawie podobieństwa znaczeniowego lub/i fonetycznego;

- afazja semantyczna - trudności związane są z rozumieniem metafor oraz skomplikowanych konstrukcji gramatycznych.

\section{Ujęcie Marii Pąchalskiej}

Maria Pąchalska poszerza termin afazji o czynniki niejęzykowe. Według niej afazję powodują uszkodzenia ośrodkowego układu nerwowego, które przyczyniają się z kolei do dezintegracji mózgowych mechanizmów budowania komunikatu (kodowania) oraz rozumienia (dekodowania) symboli niejęzykowych i językowych. Zgodnie z tą teorią Pąchalska [2012] wyróżnia trzy główne typy afazji:

- afazję kodującą - polegającą na trudnościach w rozumieniu językowego i niejęzykowego komunikatu;

- afazję dekodującą - w której wyróżnią się dwa rodzaje zakłóceń wyboru symboli oraz łączenia symboli;

- afazję mieszaną - łączącą dwa wyżej opisane typy afazji (kodującą i dekodującą), przy czym jej głęboka postać to afazja całkowita. 


\section{Diagnoza i terapia afazji}

Współczesna afazjologia najczęściej dzieli diagnostykę na specyficzną i niespecyficzną. Diagnoza specyficzna zawiera ocenę istoty zaburzeń, która w rezultacie prowadzi do klasyfikacji afazji na zespoły „korowe” i „podkorowe”, a także ocenę funkcjonalną, która określa zaburzenia funkcji mózgowych, zachowane funkcje mózgowe oraz patomechanizmy zaburzeń. Diagnoza niespecyficzna obejmuje badania rutynowe, pozwalające określić stan somatyczny oraz psychiczny pacjenta (badania neurologiczne), jak również badania standardowe, umożliwiające określenie rozległości, rodzaju i miejsca uszkodzenia mózgu. Oczywiste jest, że współcześnie bardzo ważna staje się integralność procesu diagnozy [Cieszyńska-Rożek, 2011; Pąchalska, 2012]. Zjawisko to przedstawia tabela 2.

Tabela 2. Integralność procesu diagnozy pacjentów z afazją

\begin{tabular}{|c|c|c|c|}
\hline \multirow{2}{*}{$\begin{array}{l}\text { Rodzaj } \\
\text { diagnozy }\end{array}$} & \multicolumn{3}{|c|}{ Bliższe i dalsze cele diagnozy } \\
\hline & \multicolumn{2}{|c|}{ Identyfikacja } & Określenie \\
\hline \multirow[t]{3}{*}{ Specyficzna } & Istoty zaburzeń funkcji & $\begin{array}{l}\text { Afazji na zespoły korowe } \\
\text { oraz podkorowe }\end{array}$ & \multirow{4}{*}{$\begin{array}{l}\text { Patomechanizmów, } \\
\text { zaburzeń, programu } \\
\text { rehabilitacji oraz } \\
\text { sposobów interwencji } \\
\text { medycznej }\end{array}$} \\
\hline & $\begin{array}{l}\text { Możliwości } \\
\text { funkcjonalnych }\end{array}$ & $\begin{array}{l}\text { Zachowanych funkcji } \\
\text { mózgu oraz zaburzeń }\end{array}$ & \\
\hline & $\begin{array}{l}\text { Zaburzeń psychicznych } \\
\text { i somatycznych }\end{array}$ & $\begin{array}{l}\text { Stanu psychicznego } \\
\text { i somatycznego pacjenta }\end{array}$ & \\
\hline Niespecyficzna & $\begin{array}{l}\text { Rodzaju, rozległości } \\
\text { umiejscowienia } \\
\text { uszkodzenia w mózgu }\end{array}$ & $\begin{array}{l}\text { Określenie dynamiki } \\
\text { rozwoju (ustępowanie lub } \\
\text { narastanie zmian) }\end{array}$ & \\
\hline
\end{tabular}

Źródło: Pąchalska, 2012.

\section{Diagnostyka różnicowa}

Najczęściej stosowana przez afazjologów diagnoza obejmuje dwa zespoły, w zależności od miejsca uszkodzenia mózgu. Są to zespoły: korowe (afazja: Broki, Wernickego, przewodzeniowa, amnestyczna, transkorowa motoryczna, transkorowa sensoryczna, całkowita) i podkorowe (afazja: przednia prążkowo-torebkowa, całkowita, prążkowo-torebkowa wzgórzowa). Zgodnie z tym systemem możliwe jest zaklasyfikowanie około $80 \%$ przypadków afazji powstałych w wyniku uszkodzenia mózgu.

Przedstawiona wyżej klasyfikacja odnosi się w większości do nabytych rodzajów zaburzeń, które spowodowane zostały udarem lewej półkuli. W tych przypadkach objawy występują gwałtownie, z prawostronnym niedowładem. Zespoły „korowe” diagnozuje się zazwyczaj na podstawie czterech różnych zdolności językowych, takich jak: powtarzanie słów i zdań, rozumienie wypowiedzi, wypowiadanie się oraz nazywanie. Natomiast przy diagnozie afazji podkorowych oprócz aspektów wymienionych powyżej trzeba uwzględnić trzy dodatkowe kryteria, jakimi są: praksja 
werbalna - umiejętność powtarzania słów i wyrazów, praksja oralna - zdolność wykonywania precyzyjnych i szybkich ruchów narządów mowy, hemiplegia/hemipareza - porażenie lub słabość prawej strony ciała u osób praworęcznych [Drewniak-Wołosz, Paluch, 2009; Panasiuk, 2012; Pąchalska, 2012].

\section{Rehabilitacja}

Analogicznie jak w kwestii diagnozy rehabilitacja afatyków wiąże się z wieloma teoretycznymi poglądami na temat istoty zaburzeń. Związki te wyjaśniają wiele różnic w określaniu szczegółowych celów terapii, różnorodności programów, a także metod realizacji. Niektórzy autorzy podają, że oprócz jakości mowy zewnętrznej, która jest najczęstszym kryterium warunkującym sposób terapii, wyróżnia się mowę wewnętrzną i mowę limbiczną [Mazur i wsp., 2006]. Jednym z najważniejszych celów rehabilitacji afatyka jest reintegracja psychiczna. Polega ona głównie na odbudowie zdolności i funkcji językowych. Kolejnym ważnym celem jest reintegracja społeczna, która szczególnie podkreśla aspekty podniesienia jakości życia, przywrócenia możliwości powrotu do pracy i aktywnego uczestnictwa w życiu społecznym. W celu zwiększenia skuteczności terapii należy stosować się do określonych zasad. Pierwszą i najważniejszą jest indywidualizacja ćwiczeń. Ćwiczenia należy dobrać do głębokości i rodzaju zaburzenia, a także do możliwości pacjenta. Informacje muszą być zrozumiałe. Należy stosować znane pacjentowi słownictwo - takie, które jest w stanie zrozumieć i przetworzyć. Kolejną zasadą jest stopniowanie trudności. Różne kategorie gramatyczne oraz semantyczne mogą mieć odmienny stopień trudności dla pacjentów. Zasada ta oznacza również, że krótszy materiał zawsze będzie szybciej przyswajany niż dłuższy. Następna zasada to dostępność informacji i czynności. Informacje powinny być osadzone w kontekście, a czynności możliwe do wykonania. Czwarta zasada mówi o tym, że oddziaływanie musi być wspierane konkretnymi materiałami poglądowymi, które są czytelne, przydatne i funkcjonalne. Jest to zasada poglądowości. Kolejną wskazówką jest zasada elastyczności, dotycząca zmian, jakie zachodzą podczas złożonego procesu rehabilitacyjnego i skuteczności danej metody - mogą czasem przekraczać możliwości pacjenta. Ostatnią, ale równie ważną zasadą jest przyjęcie odpowiedniej postawy psychoterapeutycznej. Terapeuta powinien być cierpliwy, kompetentny i wyrozumiały, musi rozumieć potrzeby afatyka. Niezbędne jest wytworzenie w chorym podstawy twórczej, ukierunkowanej na działanie [Krajewska, 2011; Zyss, 2011; Wiśniewska, 2002]. Czynnikami, które wpływają na efektywność procesu rehabilitacji, są: etiologia i głębokość zaburzenia, czas trwania, rodzaj afazji, składniki językowe, ewolucja zespołów afatycznych, wiek, płeć, ręczność, lokalizacja i rozległość uszkodzenia mózgu [Chantsoulis i wsp., 2010; Siudak, 2011]. 


\section{Podsumowanie}

Zaburzenie mowy, jakim jest afazja, nie ogranicza się wyłącznie do braku umiejętności tworzenia i rozumienia mowy. Każdy przypadek charakteryzuje się innymi, często nietypowymi objawami, przeplatanymi odrębnymi właściwościami determinowanymi osobniczo, dlatego diagnoza i rehabilitacja afazji jako samodzielnego zaburzenia jest niezwykle trudna. Przegląd literatury niejednokrotnie wskazuje na brak zgodności w odniesieniu do prawideł taksonomii afazji. Ze względu na rozwój tej dziedziny prognozy są dopingujące, obecnie prowadzonych jest wiele badań, mających na celu ujednolicenie fragmentacji tego zaburzenia, co powodować może podniesienie standardów opieki medycznej pacjentów afatycznych.

Literatura

Ambrosius W., Mejnartowicz J., Kozubski W., 2003, Strukturalne podstawy afazji w świetle czynnościowych metod neuroobrazowania, „Udar Mózgu”, t. 5, nr 2, s. 25-29.

Bitniok M., 2007, Rola mózgu w procesie językowego porozumiewania się - rehabilitacja logopedyczna w neurologii, „Logopeda”, nr 5, s. 7-18.

Chantsoulis M.M., Troszczyńska-Nakonieczna W., Skrzek A., Chamela-Blińska D., Sipko T., Sakowski J., 2010, The diagnosis and therapy of aphasia in acute phase, „Acta Neuropsychologica", vol. 8, no. 1, s. 38-50.

Cieszyńska-Rożek J., 2011, Terapia neurobiologiczna zaburzeń komunikacji językowej, „Nowa Logopedia", t. 2, s. 26-34.

Drewniak-Wołosz E., Paluch A., 2009, Niedokształcenie mowy o typie afazji - rozważania nad kryteriami diagnozy, „Logopaedica Lodziensia”, nr 1, s. 90-100.

Jakobson R., 1964, Dwa aspekty języka i dwa typy zakłóceń afatycznych, [w:] R. Jakobson, M. Halle (red.), Podstawy języka, Wrocław: Zakład Narodowy im. Ossolińskich, s. 107-133.

Jodzio K., Nyka W.M., 2008, Zaburzenia językowe oraz mowy w praktyce ogólnolekarskiej, „Forum Medycyny Rodzinnej", t. 2, nr 1, s. 14-22.

Kaczmarek B.L., 1995, Mózgowa organizacja mowy, Lublin: Agencja Handlowo-Wydawnicza.

Kindell J., Griffiths H., 2006, Speech and language therapy intervention for people with Alzheimer's disease, [w:] K. Bryan, J. Maxim (red.), Communication Disabilities in the Dementias, Chichester: Whurr Publishers, s. 201-237.

Krajewska M. (2011), Afazja postępująca w przebiegu otępienia czołowo-skroniowego, „Nowa Logopedia", t. 2, s. 247-262.

Krajna E. (2005), Niejednoznaczność klasyfikacji zaburzeń rozwoju mowy i języka, „Logopeda”, nr 1, s. $74-83$.

Lundgren K., Brownell H., 2016, Figurative language deficits associated with right hemisphere disorder, „Perspectives of the ASHA Special Interest Groups”, vol. 1, issue 2, s. 66-81.

Mazur R., Klimarczyk M., Rudy J., Nyka W., 2006, Wielopiętrowość zaburzeń mowy w praktyce lekarskiej, „Psychiatria”, nr 3, s. 112-117.

Nocoń P., Ziółkowska-Kochan M., Bielis R., Szeliga-Wczysła M., 2008, Zaburzenia komunikacji językowej, „Essentia Medica”, vol. 41, no. 6, s. 14-23.

Obler L., Albert M., Helm-Esabrooks N., 1985, Empty speech in Alzheimer's Disease and fluent aphasia, „Journal of Speech and Hearing Research”, no. 28, s. 405-410. 
Panasiuk J., 2012, Różnicowanie zaburzeń mowy po uszkodzeniach mózgu. Aplikacje diagnostyczno-terapeutyczne, „Nowa Logopedia”, t. 3, s. 314-320.

Papathanasiou I., Coppens P., 2018, Aphasia and neurogenic communication disorders, New York: Jones \& Barlet Learning, s. 3-5.

Pąchalska M., 2012, Afazjologia, Warszawa-Kraków: Wydawnictwo Naukowe PWN.

Sawa B., 1990, Dzieci z zaburzeniami mowy, Warszawa: Wydawnictwa Szkolne i Pedagogiczne.

Siudak A., 2011, Biologiczne uwarunkowania terapii osoby z afazją, „Nowa Logopedia”, t. 2, s. $167-189$.

Webb W., Adler R.K., 2017, Neurology for the Speech-Language Pathologist, Nashville: Elsevier.

Wiśniewska B., 2002, Terapia zaburzeń mowy, Warszawa: Wydawnictwa Szkolne i Pedagogiczne.

Wnukowska K., 2013, ABC afazji, Gdańsk: Wydawnictwo Harmonia.

Wójcik P., 2001, Zaburzenia mowy w afazji transkorowej mieszanej, „Nowa Logopedia”, t. 2, s. $264-271$.

Zyss T., 2011, Neurofizjologiczne podłoże procesu mówienia - rola somatosensorycznej kontroli zakrętów zakątowych, „Nowa Logopedia”, t. 2, s. 36-46.

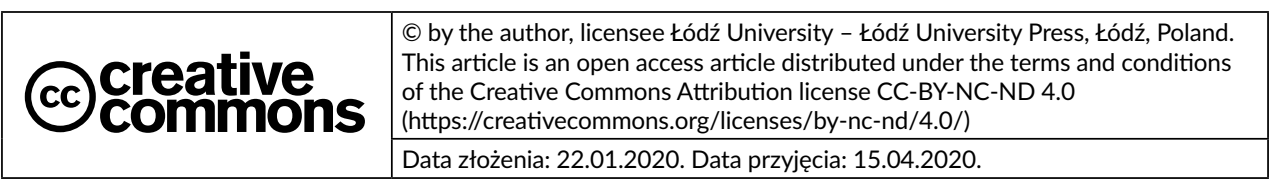

